\section{The current state of play of research on the social, political and legal dimensions of HIV}

\author{
O estado atual da pesquisa sobre as dimensões \\ sociais, políticas e legais do HIV
}

\section{Estado actual de la investigación sobre las dimensiones sociales, políticas y legales del VIH}

\section{Abstract}

1 Instituto de Psicologia, Universidade de São Paulo, São Paulo, Brasil.

2 Institute for Global Health, University of Southern

California, Los Angeles, U.S.A 3 Centre for Social Research in Health, Sydney, Australia.

4 Pathfinder International, Watertown, U.S.A.

5 School of Public Health \& Community Medicine, Sydney, Australia.

6 Sexual \& Reproductive Health Unit, Papua New Guinea Institute of Medical Research, Goroka, Papua New Guinea.

7 Hanoi Medical University Hanoi, Vietnam.

${ }_{8}$ Núcleo de Estudos de População Elza Berquó, Universidade Estadual de Campinas, Campinas, Brasil. 9 Universidad Peruana

Cayetano Heredia, Lima, Perú 10 SMS Mailman School of Public Health, Columbia University, New York, U.S.A

Correspondence

V. Paiva

Núcleo de Estudos para a Prevenção da AIDS, Instituto de Psicologia, Universidade de São Paulo.

Av. Prof. Mello Moraes 1721, São Paulo, SP 05508-900,

Brasil.

veroca@usp.br
Vera Paiva 1

Laura Ferguson 2

Peter Aggleton 3

Purnima Mane 4

Angela Kelly-Hanku 5,6

Le Minh Giang 7

Regina M. Barbosa 8

Carlos F. Caceres 9

Richard Parker 10

\section{Resumo}

This paper offers a critical overview of social science research presented at the 2014 International AIDS Conference in Melbourne, Austra lia. In an era of major biomedical advance, the political nature of HIV remains of fundamental importance. No new development can be rolled out successfully without taking into account its social and political context, and consequences Four main themes ran throughout the conference track on social and political research, law, policy and human rights: first, the importance of work with socially vulnerable groups, now increasingly referred to as "key populations"; second, continued recognition that actions and programs need to be tailored locally and contextually; third, the need for an urgent response to a rapidly growing epidemic of HIV among young people; and fourth, the negative effects of the growing criminalization of minority sexualities and people living with HIV. Lack of stress on human rights and community participation is resulting in poorer policy globally. A new research agenda is needed to respond to these challenges.

HIV; Acquired Immunodeficiency Syndrome; Human Right; Social Determinants of Health
Este artigo oferece uma perspectiva crítica da pesquisa em ciências sociais apresentada na Conferência Internacional de AIDS de Melbourne, Austrália, em 2014. Em tempos de grandes avanços no campo biomédico, a natureza política do HIV permanece de importância fundamental. Nenhuma inovação será bem-sucedida na prática se desconsiderar o contexto sociopolítico e suas consequências. Quatro temas emergiram da Conferência nos campos do direito, dos direitos humanos e da pesquisa social e política: (1) a importância do trabalho com grupos socialmente vulneráveis, crescentemente chamado de "populações chaves"; (2) o reconhecimento de que ações e programas devem ser sob medida para cada local e contexto; (3) a urgência da resposta a uma epidemia crescendo muito rapidamente entre adolescentes; (4) o efeito negativo da crescente criminalização de minorias sexuais e pessoas vivendo com HIV. Globalmente, a falta de ênfase nos direitos humanos e da participação comunitária tem como resultado políticas públicas de pior qualidade. Precisamos de uma nova agenda de pesquisa para responder a esses desafios.

HIV; Síndrome de Imunodeficiência Adquirida; Direitos Humanos; Determinantes Sociais da Saúde 
The 20th International AIDS Conference (AIDS 2014) was held in Melbourne, Australia between 20 and 25 July, 2014. Activists, scientists, policymakers, politicians and others came together to present and learn about the current state of knowledge with regard to HIV and the HIV response globally. This paper provides an overview of cutting edge research relevant to conference track D, which focused on "Social and Political Research, Law, Policy and Human Rights". It is based on individual reports and summaries from 89 plenary and abstract-driven sessions, together with symposia, workshops and bridging sessions at the conference, some of which were published on the conference website during the course of the meeting (20th International AIDS Conference. Rapporteur summaries. http:// www.aids2014.org/Default.aspx?pageId=731, accessed on 15/Nov/2014).

\section{Politics as an overarching concern}

A striking feature of the conference discourse was its recognition of the inherently political nature of the response to HIV. In plenary sessions, presentations and debates, even those focusing on clinical and epidemiological issues, we heard repeated calls to avoid an over-simplification of reality when rallying for "the end of AIDS" and "zero new infections" even though both may be important aspirations 1. Politics, as a key determinant of an effective HIV response, was recognized with much greater visibility and by a wider range of stakeholders than has been the case at recent international AIDS conferences.

The conference started with the breaking news of the crash of an aircraft from over the sky of Ukraine, which took the lives of 298 people, including several who were on their way to the conference. We all lost friends or colleagues through this tragic act of violence. As emotional as this beginning was, it also emphasized the importance of world politics, and reminded us how much the HIV epidemic has always been affected by varieties of international and interinstitutional conflict.

The importance of politics was also clear in events leading up to this conference. For example, the World Health Organization (WHO) launched the Consolidated Guidelines on HIV Prevention, Diagnosis, Treatment and Care for Key Populations ${ }^{2}$ - in which "key populations" are defined as including gay and other men who have sex with men (MSM), transgender people, sex workers, prison inmates, and people who inject drugs (PWID). The session on these guidelines emphasized the need to address "critical enablers" in- cluding community empowerment, as well as the decriminalization of these populations' practices and of HIV transmission, in places where these are illegal 2.

However, consensus on how to mitigate the disproportional HIV burden experienced by key populations was often challenged by misunderstandings and distortions. One clear example of this was the media coverage relating to pre-exposure prophylaxis (PrEP). WHO issued a strong recommendation to include PrEP as an HIV prevention strategy for MSM, which the media distorted in ways that reproduced discriminatory stereotypes. Media reports gave no recognition to the diverse levels of risk that may exist within this population group, and that may make PrEP unnecessary for many MSM, suggesting a return to notions of uniform "risk groups" that have long been abandoned in HIV prevention and research. Such misunderstanding highlighted the fact that even in an era of major biomedical advance, no new approach to prevention or treatment can be rolled out successfully without taking into account social and political circumstances and their consequences ${ }^{3}$. Such an understanding informs the perspectives on major track $D$ themes, offered below.

Four themes organize our discussion of the conference track: first, the continued importance of work with socially vulnerable groups and "key populations"; second, continued recognition that actions and programs need to be tailored locally and contextually; third, the need for an urgent response to a rapidly growing epidemic of AIDS among young people; and fourth, the negative effects of the growing criminalization of minority sexualities and people living with HIV.

\section{Key populations: shifts in terminology, intersectionality and diversity}

Over the three decades of the epidemic, numerous shifts in terminology - and conceptualization - of groups and practices have taken place; for example, from "risk groups" to "vulnerable populations" to "most-at-risk populations", and now to "key populations". These shifts often appear to portray progress (dropping stigmatizing terms in favor of more politically-correct phrases), but they do little to change the material circumstances of people who routinely face stigma and discrimination and lack of access to basic health care. Members of these key populations commented across different conference sessions that the development of new terminology by international organizations often feels like a distraction from concrete action by donors, re- 
searchers and governments, or a way to maintain a misplaced sense of optimism when things are often getting worse 4,5 .

The adoption of the term "vulnerable populations" was, in the 1990s, considered progressive by many, to the extent that it highlighted their social nature and the fact that their heightened risk was importantly explained by societal factors 6 . A subsequent term, "most-at-risk populations" (or MARPS), adopted in specific funders' language, seemed to regress to "risk groups", and was then replaced by "key affected populations" (KAPs) or, more recently, "key populations" (KPs). This series of changes may be considered to mask the social conditions in which these groups are constituted. The mass of research findings consistently describe considerable diversity within each of these KPs 7,8,9,10. Yet, the term key population seems to mask this diversity, and also fails to allow for an explicit consideration of intersectionality 11 - namely, the social inequalities (class/poverty, race/ ethnicity and gender) that cut across all these populations, rendering some of their members more systematically cut off, vulnerable and at risk than others, and highlighting the need for legal reform and increased realization of human rights in multiple contexts $12,13,14,15$. Some studies also pointed out that projects that consider members of key populations as "whole persons" rather than as vectors of diseases, are often not funded or are under-funded 16,17.

Women everywhere, but particularly female sex workers, transgender and indigenous women, about whom much was discussed in this conference, are deeply affected by this epidemic $17,18,19,20,21,22,23$. Non-realization of their right to health and persistent violations of a myriad of their human rights has led to violence and vulnerability to HIV alongside unwanted pregnancies, coerced abortions and forced sterilization 22,24,25.

Exemplary community responses to gender inequality have inspired actions locally 26 . However, too often absent from local responses are measures to ensure the health, wellbeing and human rights of people living with HIV and other key populations, and to effectively reach all groups with HIV-related services 8,21,27. Time and again, conference presenters highlighted the need for adequate resourcing for collective organization and participation, including strong mobilization by the members of most affected groups 28 .

\section{"Life is complicated": one size will never fit all}

Social life is frequently more complex than even the most sophisticated clinical trials or the lengthiest program guidelines can capture. Put simply, there are many factors influencing the way we are, how we think, and how we behave 29. HIV responses must take into account how people change throughout their lifespan, and across different structural and cultural contexts: “one size will never fit all" 27,29. Presentation after presentation at the conference highlighted how actions and programs need to be tailored locally, contextually, and historically 30 . A better understanding of local epidemics is needed in all countries, and this can best be achieved by communities being encouraged to express their views.

Participatory social science research is crucial in this respect 9,29. It has helped us understand, for example, motivations to commence taking PrEP - such as trust in the drug or the access to care that use may provide - or to stay off PrEP - such as a fear of side effects, lack of need given condom use, lack of sex, or competing health priorities 31 . Social science reported at the conference also interrogated how new prevention technologies affect issues such as stigma, highlighting how recent critiques of PrEP and an emphasis on sexual irresponsibility interfere both with the linkages between sex and pleasure, and existing and future forms of prevention 32,33 .

Although still under-utilized, communitybased empowerment is a promising approach to action with meta-analysis showing improvement in a range of HIV-related outcomes. Community leadership and involvement encourages social cohesion, collective participation and access to services ${ }^{34}$. For example, being part of a community-based organization was shown to increase quality of life and healthy behaviors among drug users 35 .

Several presentations highlighted innovative community approaches to resisting stigma and discrimination, such as the use of social media, the internet and mobile phones in outreach work with sex workers, young girls and young MSM, as well as with indigenous youth 36 . These new media can combat hopelessness and isolation, and also be powerful in highlighting "stories of resistance and survival" 37,38,39. These accounts are embedded within local cultures and therefore critical to understanding how best a local HIV response might be tailored.

Numerous speakers stressed, however, that it is often difficult to mobilize participation and identify population needs when many sexual activities remain taboo and poorly understood 
$26,40,41$. It is astonishing that, even after 25 years of the HIV epidemic, sexuality and sexual pleasure are still largely absent from discourses of prevention and care, as well as treatment as prevention. Moreover, sexual health remains set apart from reproductive health, although pregnancy and HIV infection may occur in the same sexual encounter 42 . All of this is especially important from the perspective of young people, a group often excluded from HIV-related community mobilization efforts 43 .

\section{The "exploding epidemic" among adolescents}

Numerous presentations focused on what was described as an "exploding epidemic" among adolescents (10-19 years old) 10,40. AIDS is the leading cause of death among adolescents in Africa as well as the second cause of death globally. It is remarkable that at the same time as AIDS-related deaths have fallen across all age groups, the number of adolescent deaths from AIDS has increased 40,44. Critically, about two thirds of new HIV infections among young people are among girls ${ }^{40}$. Across a wide range of contexts, HIV is concentrated in adolescent MSM, adolescents who use drugs, transgender adolescents and adolescents who sell sex. All are highly stigmatized and face exclusion from services (preventive care, protection, treatment, care and support) due to the illegality of their behaviors and/or their sexual orientation 10 .

Throughout the conference, program implementers stressed that working with young people in the lead was the only way to operate effectively. Furthermore, they noted that HIV combination prevention can also work for young people when they are involved in its design and implementation ${ }^{30}$. The need to focus on young people's creativity, resourcefulness and resilience was noted, as well as the importance of breaking down the structural barriers that make it difficult for young people to take meaningful action to protect themselves and others 43,45 .

Various sessions brought together young people from different countries and communities with leaders from governments and academia 46,47,48. Young people living with HIV were vocal during discussions advocating for their substantial (not token) participation as part of the solution. A human rights-based "youth action plan, not a youth declaration" 49 , was developed with young people's participation through an "eConsultation" and at the AIDS 2014 Youth Pre-Conference. The youth action plan calls for changing property laws and removing barriers to treatment and care; removing age-restrictions and parental consent for accessing health information and services; prioritizing laws and policies that promote young people's health over punitive laws; providing non-discriminatory, non-judgmental, rights-based, gender sensitive, youth friendly and evidence-based HIV prevention and treatment literacy; reducing stigma and discrimination; strengthening rights-based organizations; and ensuring youth participation and involvement as equal partners, with young people helping to tailor any interventions to their local context.

\section{The damaging effects of criminalization}

For the first time in a major international AIDS conference, not only was criminalization raised within the traditional contexts of law and human rights, but it was squarely part of broader discussions around HIV prevention, implementation research and intersections with other sectors beyond health. Different types of criminalization were discussed: the criminalization of HIV exposure, HIV transmission, non-disclosure of HIV status, access to HIV services for certain populations, and a range of behaviours such as sex between men, sex work and drug use. The "epidemic of bad laws" that criminalize populations and behaviours and the lack of enforcement of protective laws were widely discussed at the conference, with clear evidence presented of the negative impact of criminalization on key and other most-affected populations 26,50,51,52.

Harmful and badly designed laws perpetuate violence, hinder access to services and violate human rights. The legal situation in Nigeria, for example, is such that not only are MSM fearful of identifying themselves, but doctors, teachers and other professionals may refuse to provide services to them for fear of prosecution. Following the recent enactment of the same sex marriage (prohibition) law, the number of MSM accessing specific HIV services in Abuja, Nigeria, fell from 60 to 15 monthly. In addition, $73 \%$ of MSM surveyed expressed declining interest in attending HIV-related services following the enactment of the law 51. Unable to access formal services, MSM in Nigeria have turned to mobile phonebased networking applications to create support networks beyond official scrutiny 53 .

HIV vulnerability among young people is also exacerbated by laws that impede access to services (e.g. the prohibition of provision of contraception to unmarried girls or adolescents' need for parental consent to access HIV testing). By the age of 14 , most countries consider young people 
old enough to stand trial for a criminal offence, but many of these same countries do not consider them old enough to make decisions about their own health 54 . In many national settings, there is moreover a lack of consistency in laws about when young people can consent to sex, marry, and access sexual and reproductive health services - all of which may be disconnected from when young people actually start having sex 55,56 . Complex and contradictory laws such as these are key social and political barriers to an effective HIV response in all continents.

\section{Back to politics (and the politics of evidence)}

It is important to emphasize that, as one presentation put it, "evidence doesn't speak for itself" 57. It always has to be interpreted, and translated into practice. During the conference, delegates learned that good intentions (along with new terminologies and even new technologies) are not always matched with good programs. Throughout the meeting there was clear evidence that elements of the HIV response are likely to be most useful, especially for most affected populations, when they are tailored to context, designed to meet community needs, recognize people's autonomy, and when they ensure community engagement in all elements of the response 58,59.

People need to benefit from new biomedical technologies, but voluntarily, consciously, and without having them substitute for other effective forms of intervention 9 . For example, the introduction of PrEP should not be used as an excuse to close down or fail to establish drug-related harm reduction programs focused on needle and syringe provision or exchange, or methadone replacement therapy 28,60 . If stigma and structural vulnerability are not addressed, then replacing a biomedically sound but politically difficult strategy such as the provision of sterile injecting equipment, with a newer biomedical strategy may leave conditions of social vulnerability unaddressed. Continued work is also required to counter ideological positions that limit or impede access to effective interventions in light of clear evidence 52,61 as in the case of providing sterile injecting equipment. National authorities need to recognize the impact of the criminalization of key populations in fueling the HIV epidemic and transform legal environments to ensure that they are fully supportive of an effective HIV response for all population groups.

Evidence is available, but it is not necessarily shaping policy. This is particularly important as new challenges emerge on the horizon. Through- out the conference, clear evidence was presented of the positive impact that well-designed structural approaches can have: different sessions throughout the conference exemplified action on social drivers to end both HIV and extreme poverty $62,63,64$. Investment in social protection, while expensive, is cost-effective for countries in the long run. In South Africa, combining strategies such as the provision of cash and care (supporting family and school care) halved boys' risk of acquiring HIV and showed a cumulative impact among girls 65 . Among drug users, microfinance training and loan provision, providing practical tools to defend drug users' rights, challenging common misconceptions and building consensus among key stakeholders at the local level, increased the uptake of comprehensive services 66 . Research with MSM in India showed that those with a stronger sense of collective agency and knowledge of human rights were less likely to report experiences of violence and were more able to respond positively to HIV 62.

With 14 million people in receipt of ART, demand for second- and third-line therapies is growing in a context of increasing treatment costs exacerbated by the implementation of "free trade" agreements that impede access to generic medicines 67,68 . At the same time, funding cuts threaten the HIV response at global and national levels, especially in middle-income countries. Political priorities, encompassing trade and financing, thereby shape the feasibility of effectively addressing HIV.

\section{Towards a new agenda for action}

While the centrality of the International AIDS Conference has diminished over time (e.g. increased success in treatment access; an increased number of smaller meetings; and a simultaneous increase in on-line exchange), the meeting remains the largest biennial HIV global gathering and retains a considerable amount of symbolic impact.

Fortunately, after many attempts to discover a "magic bullet" for HIV prevention, researchers (both social and biomedical alike) increasingly accept the need for a form of "combination prevention", that is not limited to biomedical intervention. Any efficacious biomedical strategy requires both behavioral and structural components if it is to be successfully scaled up, and improving the broader legal and policy environment remains a major challenge to improving the HIV response globally. Building on this theme, one presenter issued a call for a "vaccine against intolerance", a "condom to protect against vio- 
lence" and a new form of "pre-hate prophylaxis" that will help people behave more respectfully to one other, protect people from violence and allow them to treat the effects of discrimination 8 .

Remarkably, Brazil, well known early on for its rights-based approach to HIV prevention and care 69,70 , did not provide any significant input into this debate. Presentations in the Conference discussed the national government's effort to monitor its commitment to universal access to treatment and the recent commitment to promote treatment as prevention $71,72,73,74,75,76$. On the other hand, many presentations showed how the centrality of human rights in prevention efforts have been lost, and how support for civil society participation, a principle characteristic of the Brazilian Unified National Health System (SUS), has decreased 77,78. Since 2011, challenged by increasingly vocal conservative religious clergy and politicians, the federal government has censored programmes and campaigns on non-discrimination targeting MSM and sex workers 79 . The local sustainability of landmark forms of comprehensive HIV prevention education has been undermined 80 . Unacceptably high levels of unprotected sex among MSM 81 and the growing profile of the adolescent HIV epidemic in the country 10 , can both be linked to the neglect of human rights which heightens the growing vulnerability to HIV of sex workers, MSM and transgender people 12 .

The major lessons shared at this International AIDS Conference should define the agenda for research and action on HIV. Researchers and networks committed to human rights perspectives on social, psychosocial and political research are critical to the future of the new generations still affected by this pandemic. Significant efforts are required to disseminate critical thinking, to develop methodological/technical and practical tools to country specific contexts, to promote innovative practices and protocols that consider cultural diversity at local level and change the legal context, and to share knowledge on how best to promote the participation of most vulnerable populations.

Throughout the meeting, presentations confirmed that research and interventions in countries with heightened social and programmatic vulnerability have been innovative in producing theories and methodologies that range from structural interventions to face-to-face prevention and care approaches that may help address inequality and discrimination, and lead to higher access to comprehensive health promotion and care. Networks that foster south-south collaboration seem crucial, as these innovations and perspectives that fall outside the mainstream are frequently not thought about or written up originally in English.

Countries such as South Africa, where a substantial gap still remains in ensuring universal access to HIV treatment, are involved in studies both of new biomedical prevention technologies and structural interventions, such as cash transfers to young people. Countries such as Brazil, with good access to treatment and primary health care have not so far become involved in these efforts and have done little to use the experience of others to reduce social vulnerability to HIV. Learning from these efforts is crucial to rejuvenating scientific and programming leadership.

Theoretical innovation may also benefit from this work. We need better conceptualizations of how structural and programmatic barriers produce greater vulnerability to HIV and AIDS for young people, for key populations and for other groups. It is important to remember here that terms such as "adolescent", which define an age group; and like "MSM", "sex workers" and "people who inject drugs", all of whom are defined as key populations; are themselves social products, created for specific political and social purposes that generally hide considerable diversity of perspectives, experiences, risk and vulnerability. In future work, we should never presume a universal psycho-biological profile of adolescence or youth, nor disregard the enormous differences produced by dynamics of gender, class, race, ethnicity, sexual orientation, and the laws and policies that inform education and health services.

In a world facing so many difficult challenges, one of the crucial points discussed during the conference was how to ensure that HIV remains a priority in the post-2015 development agenda. Doing this will require intensive inter-sectoral work, and broadened ways of thinking about health, not just as a technical issue, but as a political concern as well. This, at a minimum, will require a focus on universal health coverage as the path to achieving the control of HIV and maintaining people's health. This will be possible only if we manage to shift from short-term responses to long-term human rights-based approaches, addressing HIV as a broad-based social and political issue as well as a health concern. It also highlights the importance of working through human, social and economic development perspectives in order to achieve sustainable development, to create a more inclusive development agenda, and to eliminate all forms of discrimination through an on-going commitment to health and human rights 82 . 


\section{Resumen}

El artículo ofrece una perspectiva crítica de la investigación en ciencias sociales, presentada en la Conferencia Internacional de SIDA en Melbourne (Australia), 2014. En tiempos de enormes avances biomédicos, la naturaleza política del VIH sigue siendo muy importante. Ninguna innovación será exitosa sin considerar el contexto sociopolítico y sus consecuencias. Cuatro temas surgieron de la conferencia en el campo legal y derechos humanos, además de investigación social y política: (1) la importancia del trabajo con grupos socialmente vulnerables, crecientemente denominados "poblaciones claves"; (2) el reconocimiento de que las acciones y programas deben ser adaptados a un contexto local; (3) la urgencia de una respuesta a una epidemia con crecimiento rápido entre adolescentes; (4) el efecto negativo de la creciente criminalización de las minorías sexuales y personas viviendo con VIH. Globalmente, un limitado énfasis en los derechos humanos y la participación comunitaria tiene como consecuencia peores políticas públicas. Necesitamos una nueva agenda de investigación para responder a estos desafíos.

VIH; Síndrome de Inmunodeficiencia Adquirida; Derechos Humanos; Determinantes Sociales de la Salud

\section{Contributors}

V. Paiva took the lead in drafting, editing and submitting this manuscript. L. Ferguson and P. Aggleton took the lead in drafting and editing this manuscript. P. Mane, A. Kelly-Hanku, L. M. Giang, R. M. Barbosa, C. F. Caceres and R. Parker provided substantive comments and made revisions throughout the drafting process.

\section{Acknowledgments}

Martin Holt and Shalini Bharat were members of the Rapporteur team during the conference and their work, in the form of published daily web-reports is acknowledged here. The International AIDS Society provided support for Vera Paiva, Laura Ferguson, Peter Aggleton and Carlos Caceres' participation in the conference in the form of conference fee waivers, and some travel support.

\section{References}

1. Karim SSA. State of the art: epidemiology and access? In: 20th International AIDS Conference. http://pag.aids2014.org/ (accessed on 23/Sep/ 2014).

2. World Health Organization. Consolidated guidelines on HIV prevention, diagnosis, treatment and care for key populations. Geneva: World Health Organization; 2014.

3. Imrie J, Elford J, Kippax S, Hart GJ. Biomedical HIV prevention and social science. Lancet 2014 370:10-1.

4. Galloway L, Moodie R, Ighodaro M, Peltier D, Gurung N, Ketepa C. A community dialogue on key populations: who's in, who's out... and why? In: 20th International AIDS Conference. http://pag. aids2014.org/session.aspx?s=2024 (accessed on 22/Oct/2014)

5. Zhang J, Hoff C, Maughan-Brown B, Corneli A, Wilson C, Amanyeiwe U. The social and cultural context of risk and prevention. In: 20th International AIDS Conference. http://pag.aids2014.org/ session.aspx?s=1097 (accessed on 22/Oct/2014).

6. Joint United Nations Programme on HIV/AIDS. At risk and neglected: four key populations. Report on the Global AIDS Epidemic. http://www.who. int/hiv/mediacentre/2006_GR_CH05_en.pdf (accessed on 22/Oct/2014).
7. Stegling C. Why do global policies promoting access to HIV services for most vulnerable people matter at national level? In: 20th International AIDS Conference. http://pag.aids2014.org/ (accessed on 23/Sep/2014)

8. Garcia L. Stepping up the pace for men who have sex with men (MSM) and transgender: the community response. In: 20th International AIDS Conference. http://pag.aids2014.org/ (accessed on 22/ Sep/2014).

9. Mayer KH. Stepping up the pace: new prevention technologies. In: 20th International AIDS Conference. http://pag.aids2014.org/ (accessed on 23/ Sep/2014).

10. Kasedde S. The realities of adolescent key populations: what is the evidence? In: 20th International AIDS Conference. http://pag.aids2014.org/ses sion.aspx?s=1992\# (accessed on 22/Oct/2014).

11. Brah A, Phoenix A. Ain't I a woman? Revisiting intersectionality. J Int Womens Stud 2004; 5:74-86.

12. Grinsztejn B. Stepping up the pace for men who have sex with men (MSM) and transgender: understanding the science. In: 20th International AIDS Conference. http://pag.aids2014.org/ses sion.aspx?s=2010 (accessed on 22/Oct/2014). 
13. Marin M. Falling through the cracks: migrants and mobile populations. In: 20th International AIDS Conference. http://pag.aids2014.org/ (accessed on 24/Sep/2014).

14. Aher A. Challenging punitive laws in the context of criminalization of sex work and gender identity: experiences and current struggles. In: 20th International AIDS Conference. http://pag.aids2014. org/ (accessed on 22/Sep/2014).

15. McLemore M. Southern exposure: HIV and human rights in the southern United States. In: 20th International AIDS Conference. http://pag.aids2014. org/ (accessed on 24/Sep/2014).

16. Ogembo HO, Dano E, Touze G, Zamudio-Haas S, Iakobishvili E. Drug policy, harm reduction and human rights. In: 20th International AIDS Conference. http://pag.aids2014.org/session. aspx?s=1002\#3 (accessed on 22/Oct/2014).

17. Chang O. Strategies to increase participation by women who inject drugs in available harm reduction services in Dar es Salaam. In: 20th International AIDS Conference. http://pag.aids2014.org/ session.aspx?s=1002\#3 (accessed on 22/Oct/2014).

18. Shannon K, Strathdee SA, Goldenberg S, Duff P, Mwangi P, Reza-Paul S, et al. The global epidemiology of HIV among female sex workers: the influence of structural determinants. In: 20th International AIDS Conference. http://pag.aids2014.org/ (accessed on 22/Sep/2014).

19. Poteat T, Wirtz AL, Radix A, Borquez A, Silva-Santisteban A, Deutsch M, et al. HIV risk and preventive interventions in transgender women sex workers. In: 20th International AIDS Conference. http:// pag.aids2014.org/ (accessed on 23/Sep/2014).

20. van der Merwe L. Importance of key population engagement to promote sexual and gender rights in local country/region. In: 20th International AIDS Conference. http://pag.aids2014.org/ (accessed on 22/Sep/2014).

21. Luyckfasseel L. Launch of HIV prevention report card for sex workers. In: 20th International AIDS Conference. http://pag.aids2014.org/session. aspx?s=1067\#6 (accessed on 22/Oct/2014).

22. Gatsi-Mallet J. Gender inequality and HIV. In: 20th International AIDS Conference. http://pag. aids2014.org/session.aspx?s=2012\#4 (accessed on 22/Oct/2014)

23. Begg M. Addressing the specific needs of women who inject drugs - UNODC Policy Paper and Practical Guide. In: 20th International AIDS Conference. http://pag.aids2014.org/ (accessed on 22/ Sep/2014).

24. Kendall T, Albert C, Garcia G. Coercive and forced sterilization of women with HIV in Mesoamerica: findings from community-based research in El Salvador, Honduras, Mexico and Nicaragua. In: 20th International AIDS Conference. http://pag. aids2014.org/session. aspx?s=1108 (accessed on 22/Oct/2014).

25. Birgin R. Drug policy and women: addressing the negative consequences of punitive practices. In: 20th International AIDS Conference. http://pag. aids2014.org/ (accessed on 23/Sep/2014).
26. Nakato D. No one left behind: HIV and sex workers. In: 20th International AIDS Conference. http:// pag.aids2014.org/session. aspx?s=2011 (accessed on 22/Oct/2014).

27. Essajee S. Where are we headed on ending HIV and AIDS in children? In: 20th International AIDS Conference. http://pag.aids2014.org/ (accessed on 22/ Sep/2014).

28. Khuat O. No one left behind: effective drug policy and harm reduction. In: 20th International AIDS Conference. http://pag.aids2014.org/session. aspx?s=2011 (accessed on 22/Oct/2014).

29. Dybul M. Better and smarter investments in the HIV response. In: 20th International AIDS Conference. https://www.youtube.com/watch?v=xZ3o3$\mathrm{XVrdU} \&$ feature $=$ youtu.be (accessed on 22/ Oct/2014).

30. Lee H, Mane P, Bahati P, Ayalew D, Rivas J, Horrigan $\mathrm{C}$, et al. HIV/AIDS and youth: presenting biomedical, behavioral and structural interventions that work. In: 20th International AIDS Conference. http://pag.aids2014.org/ (accessed on 22/ Sep/2014).

31. Auerbach J, MacQueen K, Goicochea P, Race K, Noseda V. Public engagement with HIV science. In: 20th International AIDS Conference. http://pag. aids2014.org/session.aspx?s=2014 (accessed on 22/Oct/2014).

32. Grant B. Challenges for researching PrEP. In: 20th International AIDS Conference. http://pag. aids2014.org/ (accessed on 23/Sep/2014).

33. Kane R. Scary sex, pleasure and aversion to PrEP. In: 20th International AIDS Conference. http:// pag.aids2014.org/ (accessed on 22/Sep/2014).

34. Kerrigan D, Kennedy CE, Morgan-Thomas R, RezaPaul S, Mwangi P, Win KT, et al. A community empowerment approach to the HIV response among sex workers: effectiveness, challenges, and considerations for implementation and scale-up. In: 20th International AIDS Conference. http://pag. aids2014.org/ (accessed on 22/Sep/2014).

35. Oanh KTH. No one left behind: effective drug policy and harm reduction. In: 20th International AIDS Conference. http://pag.aids2014.org/ses sion.aspx?s=2011 (accessed on 22/Oct/2014).

36. Garcia L, Adams D, Tibamrung A, Sandler C, Calmette Y. Like me, tweet me, post me: community innovations using mobile and online technology for youth HIV programming. In: 20th International AIDS Conference. http://pag.aids2014.org/ session.aspx?s=1432 (accessed on 22/Oct/2014).

37. Rivas J. Cyber-educators in Central America: an innovative approach to reaching young MSM with combination prevention for HIV. In: 20th International AIDS Conference. http://pag.aids2014.org/ (accessed on 23/Sep/2014).

38. Bangel S. Youth engagement: reaching vulnerable populations through innovative new media recruitment and promotion. In: 20th International AIDS Conference. http://pag.aids2014.org/ (accessed on 22/Sep/2014). 
39. Demchenko M. Providing safe environments to women who inject drugs. In: 20th International AIDS Conference. http://pag.aids2014.org/ (accessed on 23/Sep/2014).

40. Kasedde S. Where are we headed with HIV and adolescents? In: 20th International AIDS Conference. http://pag.aids2014.org/session.aspx?s=2009 (accessed on 22/Oct/2014).

41. Schuenemeyer M, Njoroge N. Faith and its role in deconstructing sexual taboos. In: 20th International AIDS Conference. http://pag.aids2014.org/ (accessed on 22/Sep/2014).

42. Mukuan O, Banda A, Elaripe M, Odetoyinbo. A road map for women's rights. In: 20th International AIDS Conference. http://pag.aids2014.org/ (accessed on 22/Sep/2014).

43. Seremba A, Nininahazwe C, Minn Htet M, Nyi Nyi T. Freedom to fully control my body: what does sexual and reproductive health rights mean for young people living with HIV? In: 20th International AIDS Conference. http://pag.aids2014.org/ (accessed on 23/Sep/2014).

44. Idele P, Gillespie A, Porth T, Suzuki C, Mahy M, Kasedde S, et al. Epidemiology of HIV and AIDS among adolescents: current status, inequities, and data gaps. J Acquir Immune Defic Syndr 2014; 66 Suppl 2:S144-53.

45. Horrigan C, Lumumba M. Advocating for HIV prevention: creating the world we want for youth. In: 20th International AIDS Conference. http://pag. aids2014.org/ (accessed on 22/Sep/2014).

46. Danforth J, Williams K. Indigenous youth leadership in action. In: 20th International AIDS Conference. http://pag.aids2014.org/ (accessed on 22/ Sep/2014)

47. Munro T, Yates M. Stepping up the pace online: innovative approaches to sharing digital stories from key populations. In: 20th International AIDS Conference. http://pag.aids2014.org/ (accessed on 23/ Sep/2014).

48. Habibullah N, Agbulos KR. No longer elephant in the room: change-makers for youth and drug policy. In: 20th International AIDS Conference. http:// pag.aids2014.org/ (accessed on 22/Sep/2014).

49. Melbourne YouthForce. 2014 youth action plan. http://www.aids2014community.org/wp-content/ uploads/2014/02/MYF002-Brochure-03-PRINT. pdf (accessed on 26/Sep/2014).

50. Santos GM, Makofane K, Arreola S, Beck J, Wilson P, Hebert P, et al. Criminalization of same-sex behavior is harmful to public health: significant reductions in access to HIV prevention and care services associated with arrest and convictions for sex between men. In: 20th International AIDS Conference. http://pag.aids2014.org/ (accessed on 22/ Sep/2014)

51. Orazulike IK, Adeniyi J, Stanley O, Ononaku U, Kalu D, Doroh A, et al. Assessing policy impact on HIV intervention targeting MSM in Abuja, Nigeria. In: 20th International AIDS Conference. http:/ / pag.aids2014.org/ (accessed on 22/Sep/2014).

52. Dolan K. How the policy environment and repressive law-enforcement fuel the HIV and AIDS epidemic among people who use drugs. In: 20th International AIDS Conference. http://pag.aids2014. org/ (accessed on 23/Sep/2014).
53. Ifekandu C, Fagorusi S, Abdullahi Daniya B, Eluwa G, Luther-Onyebuchi E, Ezire O, et al. Social networking and HIV associated-sexual risk behaviours among men who have sex with men (MSM) and people who inject drugs (PWID) in Abuja Metropolis. In: 20th International AIDS Conference. http://pag.aids2014.org/ (accessed on 22/ Sep/2014).

54. Cipriani D. Children's rights and the minimum age of criminal responsibility: a global perspective. Farnham: Ashgate; 2009.

55. Elaripe M. Where are our rights in the Pacific. In: 20th International AIDS Conference. http://pag. aids2014.org/ (accessed on 22/Sep/2014).

56. Mukuan O. Women in the driving seat. In: 20th International AIDS Conference. http://pag.aids2014. org/ (accessed on 22/Sep/2014).

57. Allen ST, Ruiz MS, O'Rourke A. The evidence does not speak for itself: the role of research evidence in shaping policy change for the implementation of Publicly Funded Syringe Exchange Programs in three US Cities. In: 20th International AIDS Conference. http://pag.aids2014.org/ (accessed on 23/ Sep/2014).

58. Race K. Engagement in practice: how to grasp what is made of scientific developments. In: 20th International AIDS Conference. http://pag.aids2014. org/ (accessed on 22/Sep/2014).

59. MacQueen K. Stakeholder engagement and good participatory practices for global clinical trials: developing tools and models for the 21st century. In: 20th International AIDS Conference. http://pag. aids2014.org/session.aspx?s=2014 (accessed on 22/Oct/2014)

60. Hellard M, Luhrman N, Swan T, Nugraha S, Kamarulzaman A, Kazatchkin M, et al. Controversies in treatment as prevention for people who inject drugs. In: 20th International AIDS Conference. http://pag.aids2014.org/ (accessed on 22/ Sep/2014).

61. Hayashi K. Experiences with compulsory drug detention in Thailand: evidences from the Mitsampan community research project. In: 20th International AIDS Conference. http://pag.aids2014.org/ (accessed on 23/Sep/2014).

62. Prabhakar P. Association of human rights, community collectivization and vulnerability reduction among men having sex with men in India: myth or reality? In: 20th International AIDS Conference. http://pag.aids2014.org/session.aspx?s=1119 (accessed on 22/Oct/2014).

63. Meinck F, Stevens PE, Feeney L, Watson J. Behind the scenes: socio-economic drivers. In: 20th International AIDS Conference. http://pag.aids2014. org/session.aspx?s=1113 (accessed on 22/Oct/ 2014).

64. Iakobishvili E, Belyava O. Lawyering in the streets in Eastern Europe and Central Asia. In: 20th International AIDS Conference. http://pag.aids2014. org/ (accessed on 22/Sep/2014).

65. Cluver L, Orkin M, Boyes M, Sherr L. Effective combination prevention: cash, care and HIV-risk for adolescents in South Africa. In: 20th International AIDS Conference. http://pag.aids2014.org/ (accessed on 22/Sep/2014). 
66. Ogembo C, Angira O, Mbugua B, Abdallah S, Abdool R. Reducing vulnerability of marginalized drug dependent communities in Nairobi Kenya through socioeconomic opportunities. In: 20th International AIDS Conference. http://pag. aids2014.org/session.aspx? $\mathrm{s}=1002$ (accessed on 22/Oct/2014).

67. Bhardwaj K. EU's evolving trade agenda in developing and least developed countries: a growing threat to universal access to affordable generic medicines for HIV and hepatitis. In: 20th International AIDS Conference. http://pag.aids2014.org/ (accessed on 23/Sep/2014).

68. Gilling J. Post-2015 development and the new Australian aid paradigm. In: 20th International AIDS Conference. http://pag.aids2014.org/flash. aspx?pid=1784 (accessed on 22/Oct/2014).

69. Berkman A, Garcia J, Munoz-Laboy M, Paiva V, Parker R. A critical analysis of the Brazilian response to HIV/AIDS: lessons for controlling and mitigating the epidemic in developing countries. Am J Public Health 2005; 95:1162-72.

70. Kalichman A, Diniz S. AIDS treatment in Brazil: what kind of evidence do we need? Lancet 2009; 374:1066.

71. Valverde L, Santos E, Givisiez J, Habckost C, Taques M, Arruda M, et al. Strengthening ties between planning and M\&E: a comparison of 2012-2013 performance evaluation, Brazilian department of STD/AIDS and viral hepatitis. In: 20th International AIDS Conference. http://pag.aids2014.org/ EPosterHandler.axd?aid $=4982$ (accessed on 26/ Sep/2014).

72. Meiners-Chabin C, Pascom ARP, Freitas MA, Correa RG, Mesquita R. Towards the sustainable implementation of treatment as prevention (TasP) in Brazil: investing in policy measures to cut down on ART costs. In: 20th International AIDS Conference. http://pag.aids2014.org/ (accessed on 22/ Sep/2014).

73. Serafim D, Ayer EZ, Kraiczyk J, Neto D, Mesquita F. Combination prevention in Brazil: opportunities and challenges in the context of a concentrated epidemic. In: 20th International AIDS Conference. http://pag.aids2014.org/ (accessed on 22/ Sep/2014).

74. Batista CJB, Corrêa RG, Carvalho FO. The impact of the ARV price savings negotiation process on the sustainability of the Brazilian AIDS relief policy. In: 20th International AIDS Conference. http://pag. aids2014.org/EPosterHandler.axd?aid=6043 (accessed on 25/Sep/2014).
75. Villardi P, Vieira M, Fonseca F. Voluntary license and technology transfer for local production of Atazanavir in Brazil: a way forward or a step back to the sustainability of Brazil's universal access to ARVs policy. In: 20th International AIDS Conference. http://pag.aids2014.org/ (accessed on 22/ Sep/2014).

76. Hoffmann M, MacCarthy S, Batson A, CrawfordRoberts A, Nunn A, Vasconcelos L, et al. Testing the treatment cascade: barriers to the continuum of care among men in a large urban center of Brazil. In: 20th International AIDS Conference. http:// pag.aids2014.org / EPosterHandler.axd?aid $=4182$ (accessed on 25/Sep/2014).

77. Fonseca F, Villardi P, Vieira M. Civil society participation on AIDS policies in Brazil: a quantitative analysis of the use of access to information act. In: 20th International AIDS Conference. http://pag. aids2014.org/ (accessed on 22/Sep/2014).

78. Vieira MCF, Chaves GC, Fonseca F, Villard P. A review of the Brazilian patent law and proposals for a patent law reform from a public health and human right to health perspective. In: 20th International AIDS Conference. http://pag.aids2014.org/ (accessed on 22/Sep/2014).

79. Malta M, Beyrer C. The HIV epidemic and human rights violations in Brazil. J Int AIDS Soc 2013; 16:18817.

80. Paiva V, Bermúdez P, Silva VN, Casco R, Antunes MC, Sanchez MN, et al. Meeting religious fundamentalism panic and increasing backlash in a successful AIDS response: lessons learned from governmental and community consent process to a comprehensive condom distribution project at Brazilian schools. In: 20th International AIDS Conference. http://pag.aids2014.org/EPosterHandler. axd?aid=4396 (accessed on 25/Sep/2014).

81. Guimarães MDC, Rocha GM, Kerr LRFS, Brito AM, Dourado I. Risk behavior score for HIV based on unprotected anal sex and multiple sexual partnerships among men who have sex with men (MSM) in Brazil. In: 20th International AIDS Conference. http://pag.aids2014.org/(accessed on 22/ Sep/2014).

82. Douglas D. HIV and Small Island States post 2015: what are the key messages for the SIDS meeting in September. In: 20th International AIDS Conference. http://pag.aids2014.org/flash. aspx?pid=4933 (accessed on 31/Aug/2014)

Submitted on 18/Nov/2014

Approved on 10/Dec/2014 